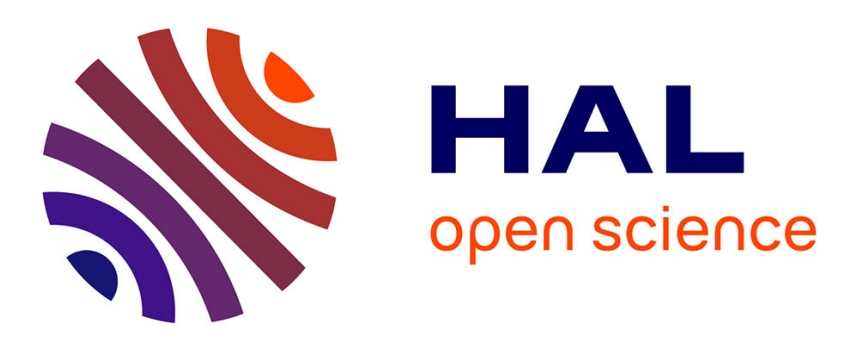

\title{
Tandem Suzuki-Miyaura Coupling/Acid-Catalyzed Cyclization between Vinyl Ether Boronates and Vinyl Halides: A Concise Approach to Polysubstituted Furans
}

Alexey N. Butkevich, Lieven Meerpoel, Ian Stansfield, Patrick Angibaud, Andrei Corbu, Janine Cossy

\section{To cite this version:}

Alexey N. Butkevich, Lieven Meerpoel, Ian Stansfield, Patrick Angibaud, Andrei Corbu, et al.. Tandem Suzuki-Miyaura Coupling/Acid-Catalyzed Cyclization between Vinyl Ether Boronates and Vinyl Halides: A Concise Approach to Polysubstituted Furans. Organic Letters, 2013, 15, pp.3840 - 3843. 10.1021/ol4014574. hal-03102290

\section{HAL Id: hal-03102290 \\ https://hal.science/hal-03102290}

Submitted on 7 Jan 2021

HAL is a multi-disciplinary open access archive for the deposit and dissemination of scientific research documents, whether they are published or not. The documents may come from teaching and research institutions in France or abroad, or from public or private research centers.
L'archive ouverte pluridisciplinaire HAL, est destinée au dépôt et à la diffusion de documents scientifiques de niveau recherche, publiés ou non, émanant des établissements d'enseignement et de recherche français ou étrangers, des laboratoires publics ou privés. 


\title{
Tandem Suzuki-Miyaura Coupling/Acid- Catalyzed Cyclization between Vinyl Ether Boronates and Vinyl Halides: A Concise Approach to Polysubstituted Furans
}

XXXX

Vol. XX, No. XX 000-000

\author{
Alexey N. Butkevich, ${ }^{\dagger}$ Lieven Meerpoel, ${ }^{\ddagger}$ Ian Stansfield, ${ }^{\S}$ Patrick Angibaud, ${ }^{\S}$ \\ Andrei Corbu, ${ }^{\dagger}$ and Janine Cossy ${ }^{*}, \dagger$
}

Laboratoire de Chimie Organique, ESPCI ParisTech, CNRS, 10 rue Vauquelin, 75231

Paris Cedex 05, France, Janssen Research \& Development, Division of Janssen-Cilag

S.A., Oncology and Medicinal Chemistry, Campus de Maigremont, 27106 Val de Reuil,

Cedex, France, and Janssen Research \& Development, Division of Janssen

Pharmaceutica NV, Turnhoutsweg 30, 2340 Beerse, Belgium

janine.cossy@espci.fr

Received May 23, 2013

ABSTRACT
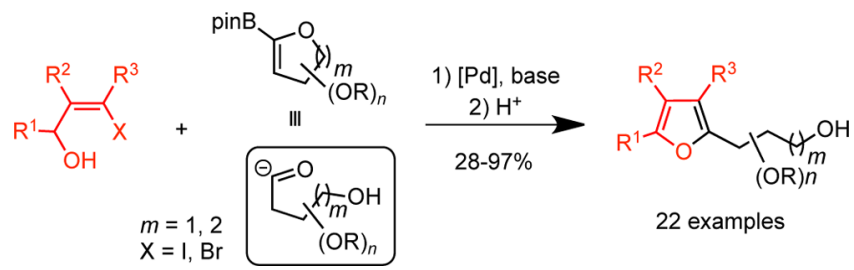

Polysubstituted 2-( $\omega$-hydroxyalkyl)furans were prepared by tandem Suzuki-Miyaura coupling/acid-catalyzed cyclization starting from appropriately substituted 3-haloallylic alcohols and dihydrofuran-, dihydropyran- or glycal-derived pinacol boronates.

The furan ring is a ubiquitous structural motif in many classes of natural products such as pheromones, ${ }^{1}$ terpenes ${ }^{2}$ and alkaloids (e.g., selaginoidine ${ }^{3 \mathrm{a}}$, nakadomarin $\mathrm{A}^{\mathrm{3b}}$ ), as well as in numerous synthetic compounds. In a recent compilation of pharmacologically active furans, ${ }^{4}$ it has been demonstrated that a variety of furans, fused furans and furanones exhibit antimicrobial, ${ }^{5}$ anti-inflammatory, antiarrhythmic or antihypertensive activities. Two among the most potent hallucinogenic compounds, salvinorin $\mathrm{A}^{6}$ (neoclerodane diterpenoid and $\kappa$-opioid receptor agonist

\section{ESPCI ParisTech}

Janssen Research \& Development, Janssen Pharmaceutica N.V.

$\S$ Janssen Research \& Development, Oncology and Medicinal Chemistry, Campus de Maigremont.

(1) Bosma, W. B.; Bartelt, R. J.; Momany, F. A. J. Org. Chem. 2006, $71,4748-4758$

(2) López-Olguín, J.; de la Torre, M. C.; Ortego, F.; Castañera, P.; Rodríguez, B. Phytochemistry 1999, 50, 749-753.

(3) (a) Panichanun, S.; Bick, I. R. C. Tetrahedron 1984, 40, 26852689. (b) Kobayashi, J.; Watanabe, D.; Kawasaki, N.; Tsuda, M. J. Org. Chem. 1997, 62, 9236-9239.

(4) Banerjee, R.; HKS, K.; Banerjee, M. Int. J. Rev. Life Sci. 2012, 2 , $7-16$.

(5) Miura, K.; Reckendorf, H. K. Prog. Med. Chem. 1967, 5, 320-381. from Salvia divinorum) and bromo-DragonFLY ${ }^{7}$ (synthetic 5- $\mathrm{HT}_{2}$ serotonin receptor agonist), contain a furan ring. Furanosteroid viridin, ${ }^{8}$ the naturally occurring fragrance rosefuran, ${ }^{9}$ the phytotoxin perilla ketone ${ }^{10}$ and unsaturated ketones rehmanones $\mathrm{A}-\mathrm{C},{ }^{11}$ all of which are diversely substituted furans, demonstrate the great variety of furan-derived natural products.

Several recent reports illustrated the synthetic utility of 2-( $\omega$-hydroxyalkyl)furan building blocks. ${ }^{12-14}$ These

(6) Ortega, A.; Blount, J. F.; Manchand, P. S. J. Chem. Soc., Perkin Trans. 1 1982, 2505-2508.

(7) Parker, M. A.; Marona-Lewicka, D.; Lucaites, V. L.; Nelson, D. L.; Nichols, D. E. J. Med. Chem. 1998, 41, 5148-5149.

(8) Grove, J. F.; McCloskey, P.; Moffatt, J. S. J. Chem. Soc. C 1966, 743.

(9) Buechi, G.; Kovats, E.; Enggist, P.; Uhde, G. Org. Lett. 1968, 33, 1227-1229.

(10) Matsuura, T. Bull. Chem. Soc. Jpn. 1957, 30, 430-431.

(11) Quiroz-Florentino, H.; Aguilar, R.; Santoyo, B. M.; Díaz, F.; Tamariz, J. Synthesis 2008, 1023-1028.

(12) (a) Robertson, J.; Meo, P.; Dallimore, J. W. P.; Doyle, B. M.; Hoarau, C. Org. Lett. 2004, 6, 3861-3863. (b) Wu, B.; Feast, G. C.; Thompson, A. L.; Robertson, J. J. Org. Chem. 2012, 77, 10623-10630.

(13) Zhu, L.; Song, L.; Tong, R. Org. Lett. 2012, 14, 5892-5895.

(14) Palmer, L. I.; de Alaniz, J. R. Org. Lett. 2013, 15, 476-479. 
compounds have served as starting materials for the preparation of spiroacetal natural products, ${ }^{12}$ cis-fused bicyclic ethers ${ }^{13}$ by a tandem Achmatowicz reaction/ spiroacetalization approach, and spirocyclic ethers by Piancatelli rearrangement. ${ }^{14}$ 2-( $\omega$-Hydroxyalkyl)furans are generally prepared by alkylation ${ }^{15}$ or acylation ${ }^{16}$ of 2-lithiofurans or by addition of organolithium reagents to furfural. ${ }^{17}$ In addition, furans with a polyhydroxylated side chain can be conveniently synthesized using the García González reaction. ${ }^{18}$ Allylation of dienol carbonates followed by a Cope rearrangement/reduction/dehydration sequence, recently proposed by our group, leads to a variety of polysubstituted furans. ${ }^{19}$ A number of metalcatalyzed furan syntheses have been developed using Au-, Hg-, Ir-, Rh-, Ru-, Pd- and Cu-catalyzed transformations of suitably substituted alkynes, allenes and cyclopropenes. ${ }^{20}$ Strong base-catalyzed ${ }^{21}$ and oxidative ${ }^{22}$ cyclizations of $^{2}$ 2-penten-4-yn-1-ols can also lead to polysubstituted furans, and acidic treatment of $\gamma$-hydroxy- $\alpha, \beta$-unsaturated ketones has been reported to induce furan ring closure under mild conditions. ${ }^{23}$

Recently, we have reported a rapid and high-yielding preparation of spiroacetals based on a tandem SuzukiMiyaura/acid-catalyzed spiroacetalization. ${ }^{24}$ Herein, we disclose the outcome of a process involving ( $Z$ )-3-haloallylic alcohols instead of 2-halobenzylic alcohols. Upon in situ acidic treatement of the Suzuki-Miyaura coupling products, substituted furans were formed instead of the expected spiroacetals (Scheme 1).

Scheme 1. Tandem Suzuki-Miyaura Coupling/Acid-catalyzed Cyclization

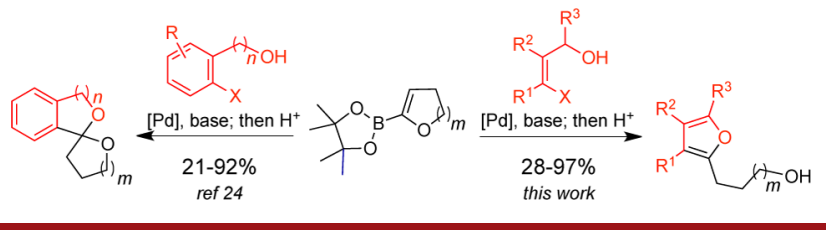

(15) (a) Stevens, K.; Madder, A. Nucleic Acids Res. 2009, 37, 1555-1565. (b) Craft, D. T.; Gung, B. W. Tetrahedron Lett. 2008, 49, 5931-5934.

(16) (a) Tofi, M.; Montagnon, T.; Georgiou, T.; Vassilikogiannakis, G. Org. Biomol. Chem. 2007, 5, 772-777. (b) Nicolaou, K. C.; Aversa, R. J.; Jin, J.; Rivas, F. J. Am. Chem. Soc. 2010, 132, 6855-6861.

(17) (a) Princival, J. L.; de Barros, S. M. G.; Comasseto, J. V.; Dos Santos, A. A. Tetrahedron Lett. 2005, 46, 4423-4425. (b) Zhou, X.; Wu, W.; Liu, X.; Lee, C.-S. Org. Lett. 2008, 10, 5525-5528.

(18) (a) Scherrmann, M.-C. Top. Curr. Chem. 2010, 295 (Carbohydrates in Sustainable Development II), 1-18. (b) Nagarapu, L.; Chary, M. V.; Satyender, A.; Supriya, B.; Bantu, R. Synthesis 2009, 2278-2282. (c) Bartoli, G.; Fernández-Bolaños, J. G.; Di Antonio, G.; Foglia, G.; Giuli, S.; Gunnella, R.; Mancinelli, M.; Marcantoni, E.; Paoletti, M. J. Org. Chem. 2007, 72, 6029-6036.

(19) Fournier, J.; Arseniyadis, S.; Cossy, J. Angew. Chem., Int. Ed. 2012, 51, 7562-7566.

(20) (a) Gulevich, A. V.; Dudnik, A. S.; Chernyak, N.; Gevorgyan, V. Chem. Rev. 2013, 113, 3084-3213. (b) Kirsch, S. F. Org. Biomol. Chem. 2006, 4, 2076 and references therein.

(21) Marshall, J. A.; Bennett, C. E. J. Org. Chem. 1994, 59, 61106113 .

(22) (a) Du, X.; Chen, H.; Liu, Y. Chem.-Eur. J. 2008, 14, 9495 9498. (b) Du, X.; Chen, H.; Chen, Y.; Chen, J.; Liu, Y. Synlett 2011, $1010-1014$.
Employing the conditions optimized for the crosscoupling of aryl bromides and aryl iodides $\left[\mathrm{Pd}(\mathrm{dppf}) \mathrm{Cl}_{2}\right.$ ( $2 \mathrm{~mol} \%$ ), $\mathrm{NaOH}$ (2 equiv), dioxane $/ \mathrm{H}_{2} \mathrm{O}$ (4:1), microwave irradiation $(\mathrm{MW}), 100{ }^{\circ} \mathrm{C}, 10 \mathrm{~min}$ followed by $p \mathrm{TsOH}$ ( 2.2 equiv), rt, $10 \mathrm{~min}$ ] to a panel of subsituted 3-bromoor 3-iodoallylic alcohols, a series of polysubstituted 2-( $\omega$ hydroxyalkyl)furans were successfully prepared in moderate to excellent yields (Table 1). ${ }^{23}$

Table 1. Preparation of Furans 13-23

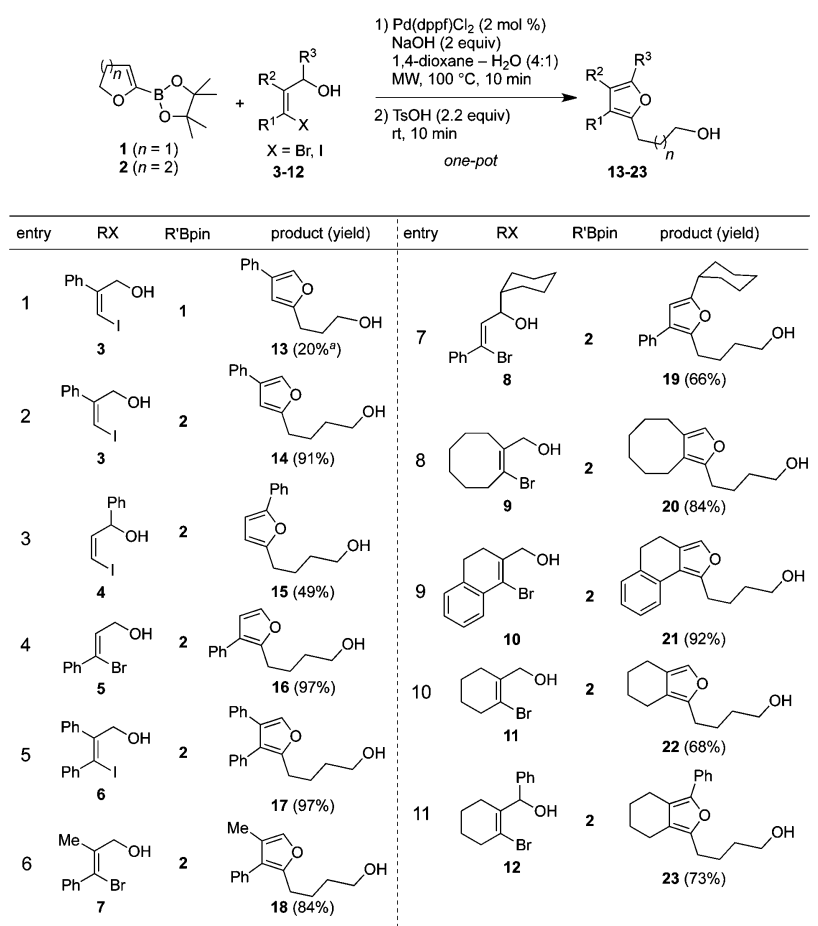

${ }^{a}$ Yield increased to $34 \%$ when the cross-coupling was performed under anhydrous conditions ( $\mathrm{MeCN}, 2$ equiv $\mathrm{Cs}_{2} \mathrm{CO}_{3}$ ); 3 equiv of TsOH was used for cyclization.

The halogenated allylic alcohols were prepared according to literature procedures. ${ }^{25}$ From a reactivity standpoint, there was no difference between bromo- and iodoalkenes under the Suzuki-Miyaura coupling conditions, so the substrates were chosen according to their ease of access. The alcohols 3-12 were treated with boronate $\mathbf{1}$ or $\mathbf{2}$ under the previously described conditions. ${ }^{24}$ The coupling with dihydrofuranyl boronate 1 (Table 1, entry 1) suffered from significantly lower yield because of the sensitivity of the starting boronate and the cross-coupling intermediate. The yields with boronate $\mathbf{2}$ were generally good to excellent for both 3-bromo- and 3-iodoallylic alcohols. 2,3-, 2,4-, 2,5-disubstitued furans (Table 1, entries 1-4), 2,3,4- and 2,3,5-trisubstituted (Table 1,

(23) (a) Iriye, R.; Uno, T.; Ohwa, I.; Konishi, A. Agric. Biol. Chem. 1990, 54, 1841-1843. (b) Lee, P. H.; Kim, H. S.; Kim, S. Chem. Lett. 1994, 2401-2402. (c) Sammond, D. M.; Sammakia, T. Tetrahedron Lett. 1996, 37, 6065-6068. (d) Donohoe, T. J.; Bower, J. F. Proc. Natl. Acad. Sci. U.S.A. 2010, 107, 3373-3376.

(24) Butkevich, A. N.; Corbu, A.; Meerpoel, L.; Stansfield, I.; Angibaud, P.; Bonnet, P.; Cossy, J. Org. Lett. 2012, 14, 4998-5001. 
entries 5-7) and fused furans (Table 1, entries 8-11) have been prepared by this one-pot procedure.

The Suzuki-Miyaura coupling intermediates containing 1-aryl- or 1-alkynyl-2-propen-1-ol fragments proved particularly acid sensitive and required the use of the weaker trifluoroacetic acid ${ }^{26}$ instead of $p \mathrm{TsOH}$ to increase the yield of furans (Table 2). Under these conditions, several 2,5-disubstituted and 2,3,5-trisubstituted furans were prepared.

Table 2. Preparation of Furans 15 and 31-37
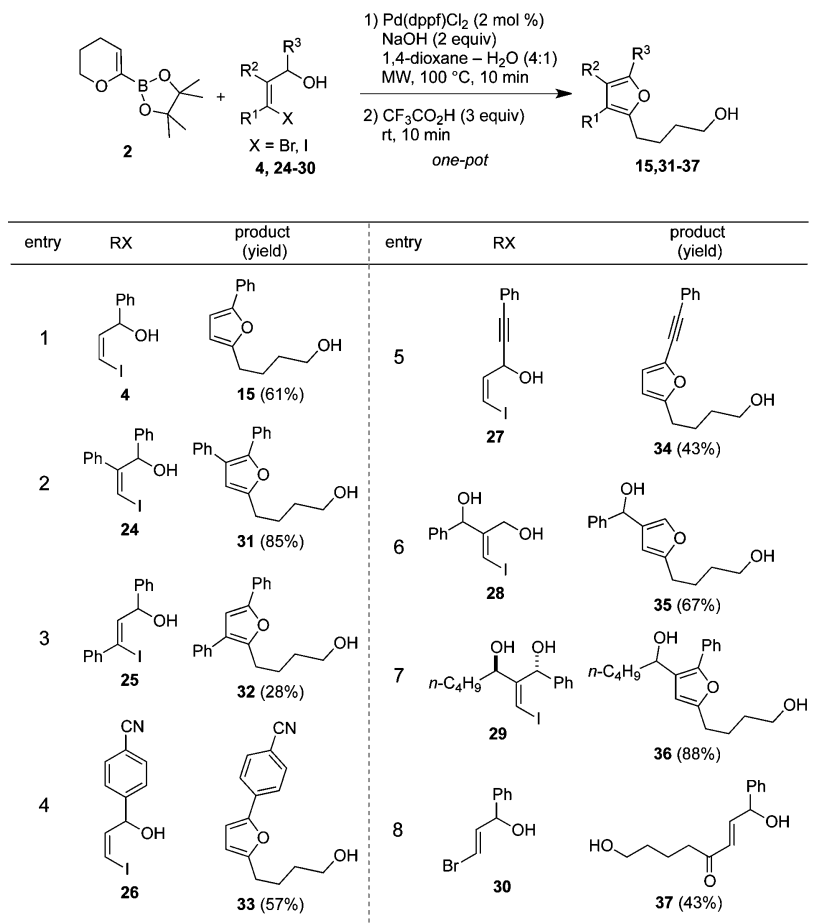

The reaction is regioselective as only the disubstituted furan $\mathbf{3 5}$ was obtained from allylic diol $\mathbf{2 8}$ and diol $\mathbf{2 9}$ was converted to the trisubstituted furan 36 (Table 2, entries 6 and 7 ), suggesting that only $(Z)$-allylic alcohols cyclize to the corresponding furans. Indeed, the $(E)$-allylic alcohol 30 produced the corresponding $\alpha, \beta$-unsaturated ketone $\mathbf{3 7}$ as the only major product in $43 \%$ yield (Table 2 , entry 8 ). This result indicates that the cyclization of $(Z)$-allylic alcohols to furans proceeds much faster than the possible acid-catalyzed $E / Z$-isomerization of the double bond. ${ }^{27}$

The preparation of furans possessing a polysubstituted side chain was next investigated. The starting glycal boronates were prepared by $\mathrm{Ir}$-catalyzed $\mathrm{C}-\mathrm{H}$ borylation of glycals 38-40 described by Miyaura et al. $\left\{\mathrm{B}_{2} \mathrm{pin}_{2}(1.2\right.$ equiv), $[\operatorname{Ir}(\operatorname{cod})(\mathrm{OMe})]_{2}(1.5 \mathrm{~mol} \mathrm{\%})$, dtbpy $(3 \mathrm{~mol} \%)$ in hexane $\}.{ }^{28}$ The reaction was regioselective for glucose

(25) See Supporting Information.

(26) Guthrie, J. P. Can. J. Chem. 1977, 2342-2354.

(27) (a) Nokami, J.; Nishimura, A.; Sunami, M.; Wakabayashi, S. Tetrahedron Lett. 1987, 28, 649-650. (b) Boto, A.; Hernández, D.; Hernández, R. Org. Lett. 2007, 9, 1721-1724. derivatives but required prolonged heating $(8-16 \mathrm{~h}$ in hexane at $80^{\circ} \mathrm{C}$ ). However, under microwave irradiation, in the presence of an inert microwave absorber (graphite powder) the reaction temperature was increased to $120^{\circ} \mathrm{C}$ and the borylation was complete within $15 \mathrm{~min}$, attaining $80-90 \%$ conversion of the starting glycal to the corresponding C6-boronate (GC control). The crude boronates thus obtained were used directly in the cross-coupling/ cyclization sequence upon filtration through a short pad of silica and concentration of the filtrate.

The dihydropyranyl pinacol boronates, prepared from tri- $O$-methyl-D-glucal 38 and tri- $O$-methyl-D-galactal 39 were involved in the cross-coupling/cyclization process to form furans 41-43 with polysubstituted side chains in $40-91 \%$ yields (Table 3 , entries $1-3$ ). As benzyl protecting groups were found incompatible with the borylation conditions (due to competing borylation of the aromatic ring), the transformation was instead performed on glycal

Table 3. Preparation of Polysubstituted Furans by Tandem Borylation/Cross-coupling/Cyclization of Glycals

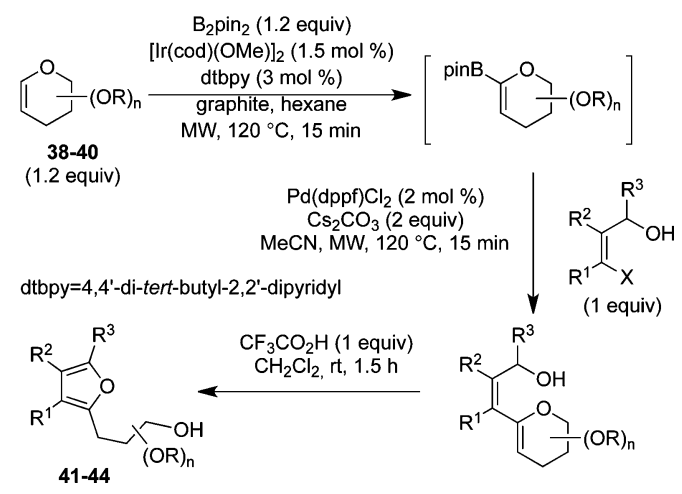

\begin{tabular}{|c|c|c|c|}
\hline entry & glycal & $R X$ & $\begin{array}{c}\text { product } \\
\text { (yield) }\end{array}$ \\
\hline
\end{tabular}
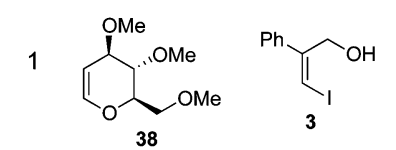<smiles>COC[C@H](O)[C@@H](OC)[C@H](Cc1cc(-c2ccccc2)co1)OC</smiles>

2
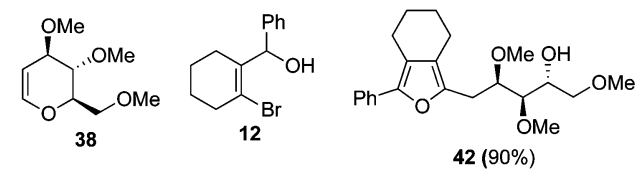

3

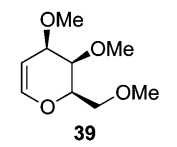

12

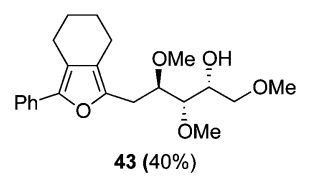

4
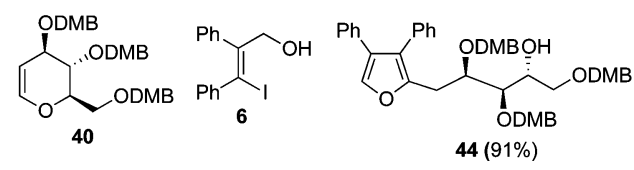

${ }^{a}$ The intermediate vinyl dihydropyran cross-coupling product could be isolated in $65 \%$ yield, see Supporting Information for details. $\mathrm{DMB}=3,5$-dimethylbenzyl. 
ether $\mathbf{4 0}$ protected as a tris-3,5-dimethylbenzyl (DMB) ether. ${ }^{29}$ The corresponding trisubstituted furan $\mathbf{4 4}$ was obtained in $91 \%$ yield (Table 3 , entry 4 ).

Scheme 2. Tandem Suzuki-Miyaura Coupling/Acid-catalyzed Cyclization: A Mechanistic View
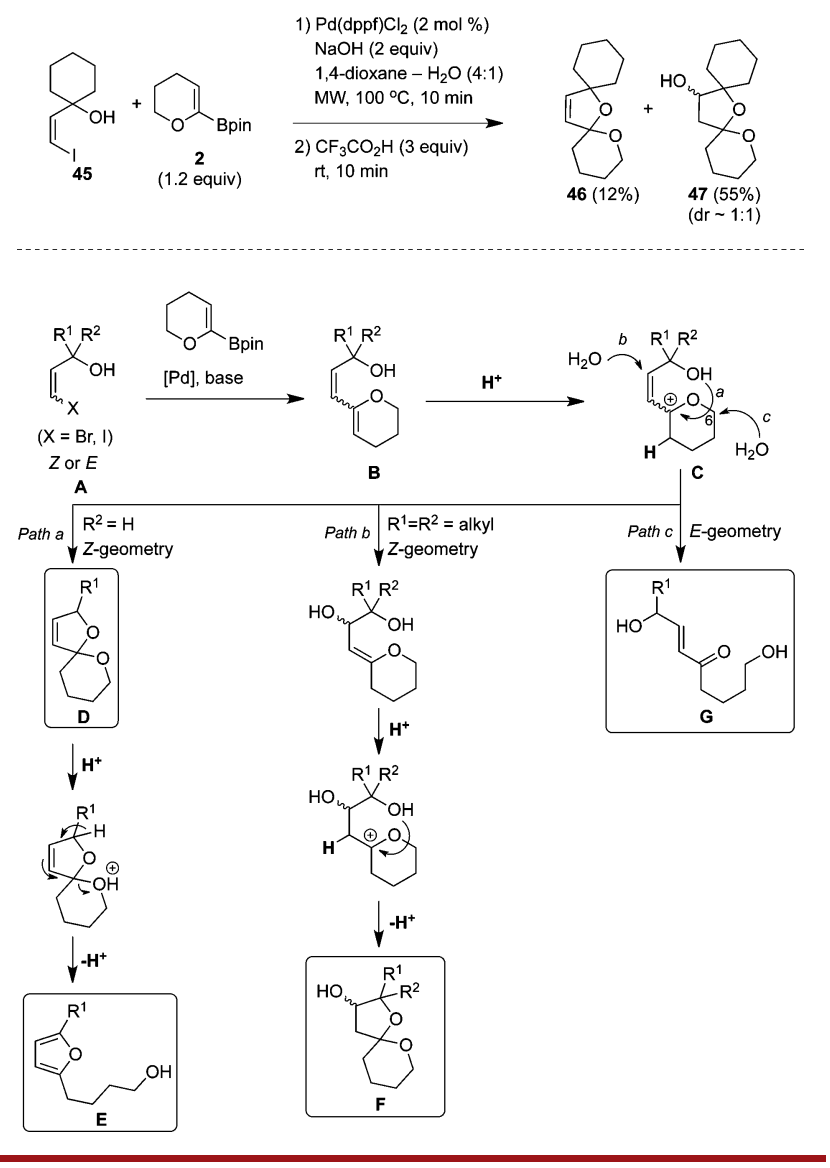

The proposed overall reaction mechanism of the described preparation of furans is presented in Scheme 2.

(28) Kikuchi, T.; Takagi, J.; Isou, H.; Ishiyama, T.; Miyaura, N. Chem.-Asian J. 2008, 3, 2082-2090. 4173 .
Once the cross-coupling intermediate $\mathbf{B}$ is protonated, the resulting carbocation $\mathbf{C}$ has three possible pathways $(\mathrm{a}-\mathrm{c})$ dictated by its structural constraints. Path a leads, by a kinetically favored 5-endo-trig spiroacetalization followed by a protonation/aromatization cascade, to the target polysubstituted furans $\mathbf{E}$. To prove that the formation of furans proceeds through a spiroacetal intermediate D, 1,1-disubstituted 3-iodoallylic alcohol $\mathbf{4 5}$ was prepared and subjected to the same cross-coupling/ cyclization sequence. The expected 2,5-dihydrofuran spiroacetal $\mathbf{4 6}^{30}$ was isolated as a minor product along with the diastereomeric products of the double bond hydration $(\mathbf{4 7 a}, \mathbf{b})$. This result can be explained if an alternative Path $b$ is followed when the aromatization step is not possible. Finally, if the starting allylic alcohol possesses an (E)-configuration, the ringopening at the $\mathrm{C} 6-\mathrm{O}$ bond with the formation of an $\alpha, \beta$-unsaturated ketone $\mathbf{G}$ is thermodynamically preferred (Path c).

In summary, we have developed a microwave-assisted synthesis of polysubstituted furans with a 2-( $\omega$-hydroxyalkyl) side chain by a tandem one-pot Suzuki-Miyaura coupling/ acid-catalyzed cyclization sequence. The scope and limitations of the process have been evaluated. The proposed method provides rapid access to a variety of alkyl- and aryl-substituted furans and may be applied to the synthesis of complex molecules, such as pharmaceuticals and natural products.

Acknowledgment. Janssen Pharmaceutica is gratefully acknowledged for financial support.

Supporting Information Available. Full experimental details and characterization data $\left({ }^{1} \mathrm{H}\right.$ NMR,${ }^{13} \mathrm{C}$ NMR, IR and HRMS) for all new compounds. This material is available free of charge via the Internet at http://pubs.acs. org.

(30) (a) Whitby, R.; Kocieński, P. Tetrahedron Lett. 1987, 28, 36193622. (b) Kocieński, P.; Whitby, R. Synthesis 1991, 1029-1038.

The authors declare no competing financial interest. 